\title{
Introducing the Hiking Suitability Index to evaluate mountain forest roads as poten- tial hiking routes - a case study in Hatila Valley National Park, Turkey
}

\author{
Hilal Turgut, Ayse Yavuz Ozalp \& Halil Akinci
}

Keywords: National Park, outdoor activities, geographic information system, analytic hierarchy process

\section{Abstract}

Planning recreational areas for a conservation-use balance is important in the sustainable use of national parks. This study was conducted to determine the suitability of forest roads as hiking routes in Hatila Valley National Park, northeastern Turkey. The indicators used as evaluation criteria were determined using the natural characteristics and landscape values of the National Park. A multi-criteria decision analysis (the Analytic Hierarchy Process; AHP) was used, with route length, slope, altitude, aspect, walking time, landscape quality and access to clean water as the main parameters. Experts were consulted to determine the weights of parameters and the linear scoring functions. Expert opinions were also used for scoring measurable and unmeasurable sub-parameters. A Hiking Suitability Index (HSI) was formulated using these parameters to score the suitability of existing roads for hiking. A Geographic Information System (GIS) was used to map the parameters and hiking routes. Results showed that slope was the most important parameter in assessing suitability. We concluded that forest roads can be used for hiking in protected areas without harming nature, and the suitability of routes can be determined using AHP.

\section{Profile}

Protected area

Hatila Valley National

Park

Mountain range

Kaçkar Mountains

Country

Turkey

\section{Introduction}

Hiking, trekking and mountaineering are often used as synonyms. In particular, hiking and trekking are often used interchangeably, though in fact they refer to different things. Trekking is an outdoor walking activity with a duration of more than a day; daytrips are called hiking (Oksuz 2020). Hiking is perceived as light walking to commune with nature and is practised especially as a weekend activity to get away from the pace of life in big cities.

People undertake nature sports to acquire and develop physical, social and mental skills, to commune with nature, ease stress and promote health (Ardahan \& Mert 2013; Kaplan \& Ardahan 2013). After walking, people report feeling mentally rested, having better control over their lives, a sense of pride, a boost in selfconfidence, and having felt close to nature (Arnberger et al. 2002; den Breejen 2007); some develop a greater awareness of nature conservation (Solnit 2001). In recent years, many protected areas have become destinations for nature-based tourism activities (Mason 2005). National parks (NP) are the most popular areas for such activities (Kaczynski \& Henderson 2007). Furthermore, it is known that using NPs for nature sports increases visitor satisfaction and the demand for these areas (Ping et al. 2017; Schirpke et al. 2018).

The careful planning of recreation areas is necessary because the demand for outdoor recreation has grown continuously. People's expectations of what the landscape has to offer (and the limitations that they will accept) have to be met by recreation planners, and this depends on the extent of the land base and its current uses, its variety and robustness, the climate, and alternative opportunities (Bell 1997). Recent studies on recreational areas have focused on issues such as sustainability in natural areas with a high potential for recreational activities, landscape metrics, diversity of use, the identification of suitable areas, and the ecological impacts that might result from recreational uses. In these studies, Geographic Information Systems (GIS) and remote sensing techniques were used extensively (Weaver 2002; Beedie \& Hudson 2003; Nyaupane et al. 2004; Báez 2002 Nepal 2006; Tsaur et al. 2006; den Breejen 2007; Gunes \& Hens 2007; García-Frapolli et al. 2007, Chakrabarty 2011; Hai-ling et al. 2011; Bunruamkaew \& Murayama 2011; Kiper 2011; Tomczyk 2011; Li et al. 2012; Ween \& Abram 2012; Nahuelhual et al. 2013).

In early studies on hiking activities, duration emerged as a consideration, and thus Naismith (1892) developed the theory of walking time. Subsequent studies focused on parameters affecting walking, such as ground conditions, weather conditions, physical conditions of hikers, fatigue, and the load carried by hikers (Fritz \& Carver 1998; Rees 2004; Scarf \& Grehan 2005; Scarf 2007; Sonneveld et al. 2009; Erbaş et al. 2011; Magyari-Saska \& Dombay 2012; Pitman et al. 2012). Outdoor sports in natural areas are favourite recreational activities. In a study carried out to determine the spatial requirements of outdoor activities, Kramer and Roth (2002) used morphological properties such as slope, aspect and altitude, landscape characteristics such as vegetation, use of the landscape by agriculture, forestry and settlement, as well as climatic parameters such as temperature and pre- 

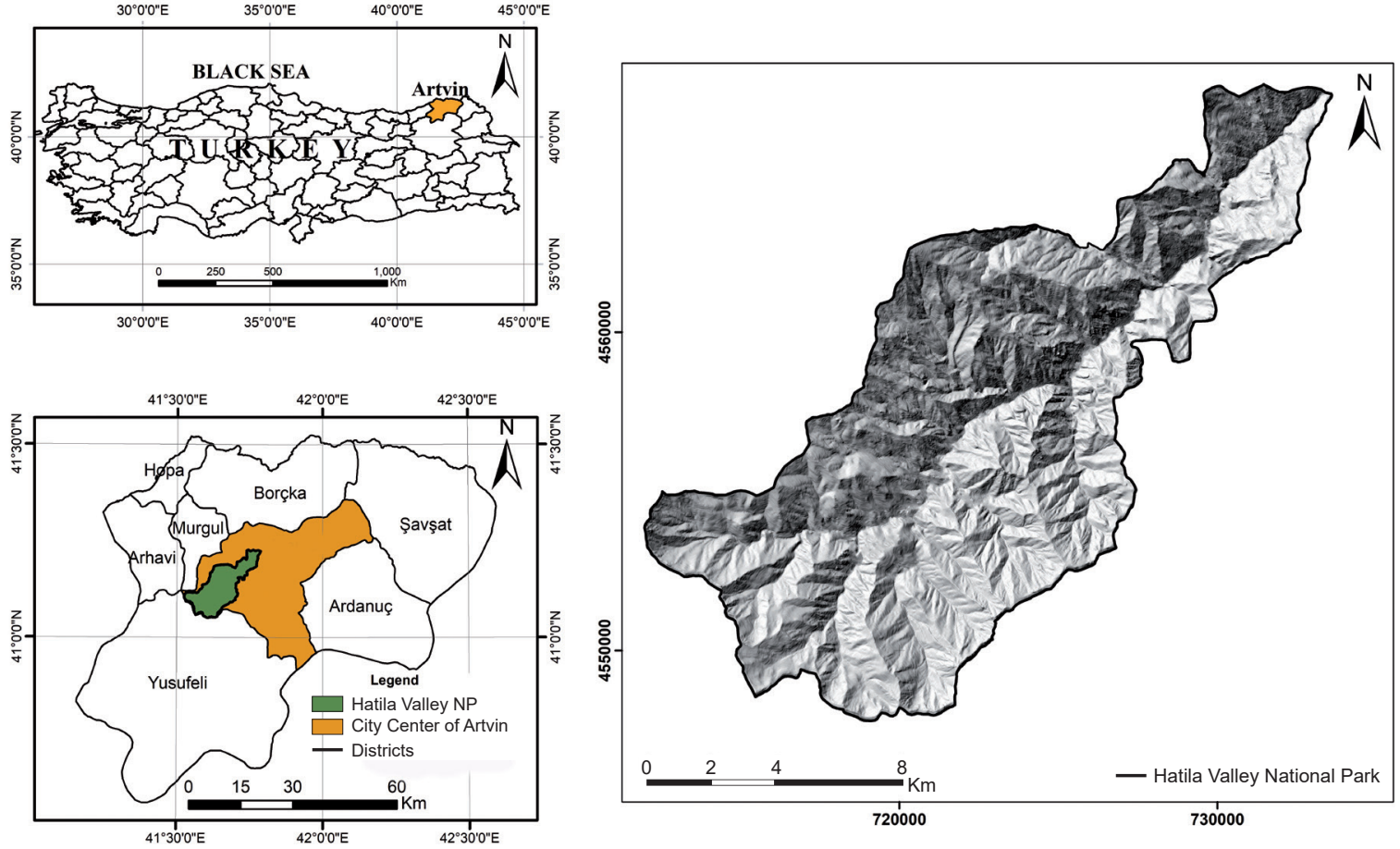

Figure 1 - Location of the study area. (C) 2020 General directorate of mapping

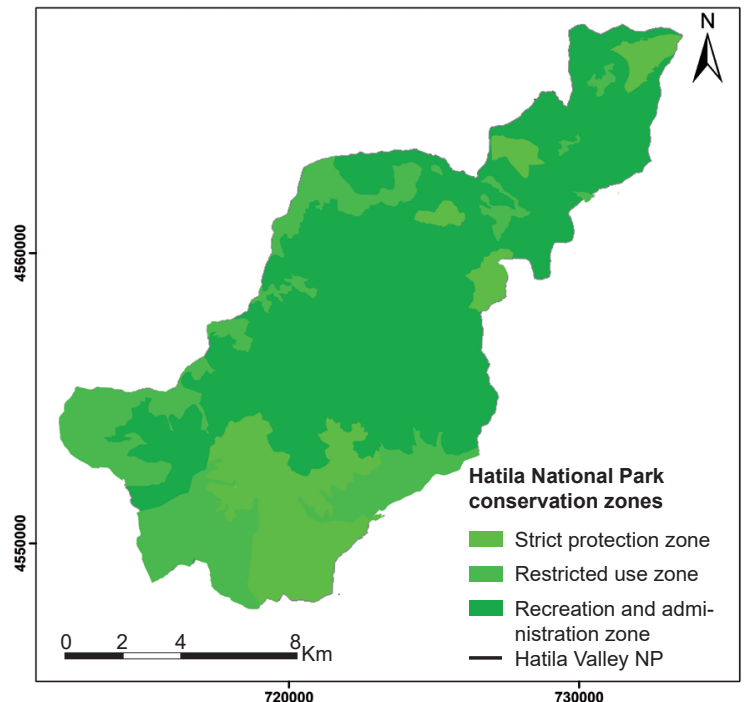

Figure 2 - The conservation zones of Hatila Valley National Park. (C) 2020 General directorate of mapping

cipitation in the evaluation process (Kramer \& Roth 2002). A study conducted by De Valck et al. (2017) to determine the effects of landscape characteristics on people's outdoor activity preferences used distance from home, facilities, trail quality, tranquility, presence of water, and landscape openness, naturalness and diversity as evaluation criteria. In determining suitable routes for hiking, in addition to the topography, the share of landscape types (e.g. riverine forest, pine forest, bushes, meadows, agriculture, water, industry, buildings), infrastructure (e.g. number of benches), and attractions (e.g. picnic spot, restaurant, museum of natural history) were also taken into consideration
(Taczanowska et al. 2008a). In Vias et al. (2018), route suitability was evaluated by applying criteria such as choice of the start- and endpoints of the route, suitability of the sections that constitute the route, route circularity, inclusion or not of a section of the trail in paths used by the general public or in the livestock trail. It is well known that route planning and the development of activities increase walkers' satisfaction and interest in natural areas, and encourage people to do outdoor sports (Ping et al. 2017).

Hatila Valley NP, which received its conservation status in 1994, is important for its rich biodiversity (Anşin et al. 2000; Kurdoğlu \& Çokçalışkan 2011), scenery with high landscape value, geological and geomorphological formations, and the presence of water. Home to important ecosystems, the area offers educational and recreational activities. The settlements within the boundaries of the Hatila Valley NP and the paths and forest roads that connect them constitute important opportunities for hiking. This study aimed to determine the suitability of forest roads as hiking routes in Hatila Valley NP using the Analytical Hierarchy Process (AHP) and GIS. The main reason for choosing the Hatila Valley NP as our study area was the fact that it is the most preferred area for outdoor activities.

\section{Materials and method}

\section{Study area}

Located in Turkey's Eastern Black Sea Region, Artvin is a city of approximately $7367 \mathrm{~km}^{2}$. Hatila Valley NP is located $6.8 \mathrm{~km}$ northwest of the city centre, between $41^{\circ} 02$ ' 49.74 " and $41^{\circ} 13$ ' $58.64^{\prime \prime}$ North, and 
$41^{\circ} 31^{\prime} 21.06^{\prime \prime}$ and $41^{\circ} 47^{\prime} 12.89^{\prime \prime}$ East (Figure 1). The total area of the study field is 16944 ha. Hatila Valley NP, where 135 floristically rare endemic taxa are found, is one of the few areas where Mediterranean, Black Sea and Alpine meadow vegetation are all found, as well as a considerable number of medical and aromatic plants (Anşin et al. 2000). The Hatila Valley NP includes three conservation zones: the strict protection zone, a restricted-use zone, and a recreation and administration zone (Figure 2). While the annual number of visitors to the Hatila Valley NP was just 500 until 2016, it increased to 30000 after infrastructure and facilities were built in 2016.

\section{The physical properties of the field}

The altitude in the Hatila Valley NP ranges between $170 \mathrm{~m}$ and $3220 \mathrm{~m}$, averaging $1724 \mathrm{~m}$ (Figure 3a). Differences in altitude over short distances increase the attractiveness of the area for hiking by creating rich route options. Hatila Valley NP, through which the Hatila stream flows, is a young V-shaped valley. The valley sides are quite steep because of the strong vertical erosion (Figure $3 \mathrm{~b}$ ). The valley is covered with natural old forests. $38 \%$ of the forest area is sunny; $62 \%$ is shady (Figure 3c).

\section{Materials}

The materials of this study were forest roads that connect the remotest parts of the forest to the main road in the Hatila Valley NP. They provide access to the forest for timber management, fish and wildlife habitat improvement, fire control, hunting, and a variety of recreational activities (Northern Research Station n.d.). This study looked at the suitability for hiking of 11 routes (walking time up to 8 hours, with different start- and endpoints, and safe) along the forest road network within the borders of Hatila Valley NP (Figure 4).

\section{Method}

The Analytic Hierarchy Process (AHP) was used to determine the level of suitability of potential hiking routes in Hatila Valley NP, in a four-stage process:

- choosing the main parameters;

- weighting the main parameters using AHP;

- scoring the sub-parameters using linear scoring functions and expert opinion;

- calculating the hiking suitability index using GIS.

\section{Choosing the main parameters}

The first stage of the AHP was to determine the parameters to be used in decision-making and the evaluation of the hiking routes. The opinions of 30 members of the Patika hiking club were gathered. Participants were asked to score properties relating to morphology, infrastructure and landscape that affect their hiking preferences according to a 3-point Likert scale (not important, don't know, important). Seven parameters that respondents said were important were
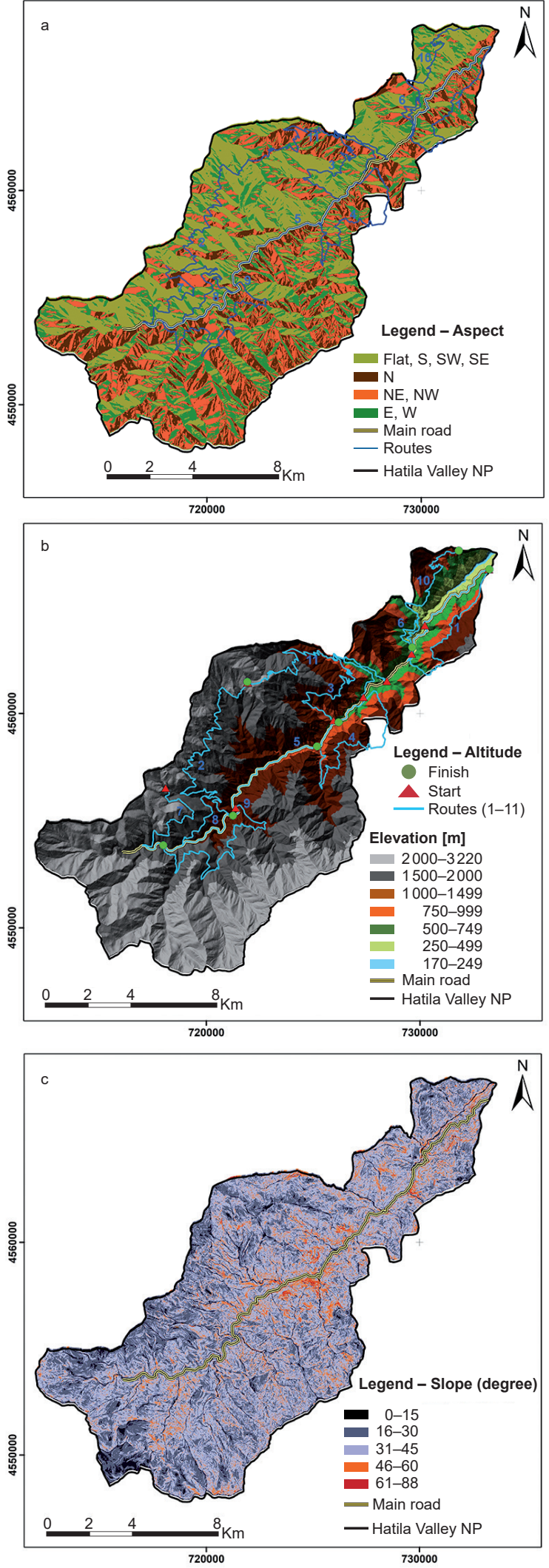

Figure 3 - Maps showing (a) aspect, (b) altitude, and (c) slope in Hatila Valley National Park. (C2020 General directorate of mapping 


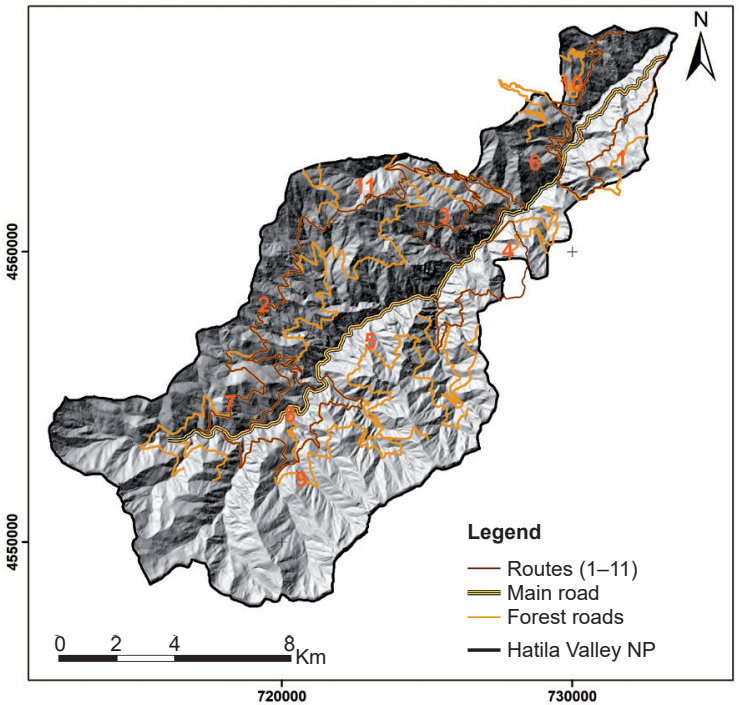

Figure 4 - The forest road network and routes. (C) 2020 General directorate of mapping

chosen as evaluation parameters (altitude, slope, aspect, walking time, distance, access to clean water, and landscape quality). ArcGIS 10.2 software was used to digitize the parameters and to create a digital elevation model (DEM) of the site. Some descriptive information of the main parameters, based on the views of experts, is given below.

\section{Altitude}

Areas between $1500 \mathrm{~m}$ and $3500 \mathrm{~m}$ are considered high; ones between $3500 \mathrm{~m}$ and $5000 \mathrm{~m}$ are considered very high. There are differences in body functions depending on altitude, due especially to decreased oxygen $\left(\mathrm{O}_{2}\right)$ levels in the air as altitude increases. While there are no differences in body functions up to $1000 \mathrm{~m}$, there are slight changes between $1000 \mathrm{~m}$ and $1500 \mathrm{~m}$. Above $1500 \mathrm{~m}$, a decrease of $3-3.5 \%$ in $\mathrm{O}_{2}$ for every altitude increase of $300 \mathrm{~m}$ negatively affects many body functions, especially blood pressure. At altitudes of over 3000, a two-night stay is needed for every $300 \mathrm{~m}$ of ascent for blood pressure to adapt (Kanai et al. 2001; Wagner et al. 2006; Bhaumik et al. 2008).

\section{Slope}

Hiking routes consist of descents, ascents and level sections, depending on the topography. Continuous descents and ascents along a route and slopes affect a route's suitability. In this study, the routes were divided into line segments using the Split Line at Vertices geoprocessing method of ArcGIS 10.2. The start-and endpoints of each line segment were determined according to the direction of the route. Then, using the Extract Values to Points method in ArcGIS 10.2, the altitudes of the start- and endpoints of each segment were obtained. Using the altitude differences between these points and the length of the line segments, the slope of each segment was calculated, and finally the average slope.

\section{Aspect}

As discussed in the literature and as stated by the experts consulted for our study (see 1.4.2 below), aspect analysis becomes crucial when examining hiking in valleys as the two sides of a valley face in different directions (Y1lmaz \& Memluk 2008). The hemisphere where the hiking is taking place, the season, and the region's climate characteristics emerge as key factors. In the northern hemisphere, regions facing north and shady areas are preferred for summer hiking activities; regions facing south and sunny areas are preferred in winter. Because of snow cover, most activities are carried out in the summer.

\section{Distance}

The findings from the interviews showed that people preferred walking routes that were neither too long nor too short. The geological fault lines in Hatila Valley NP and the blind valley are characteristic of the area. When the actual lengths of the walking routes in the area and the projected lengths were compared, differences of between $170 \mathrm{~m}$ and $820 \mathrm{~m}$ were found. It is therefore more meaningful to use the actual lengths in calculations, which in our study ranged from $7500 \mathrm{~m}$ to $17000 \mathrm{~m}$.

\section{Walking time (Duration)}

Under normal conditions, the distance that one person can cover in an hour is between $4000 \mathrm{~m}$ and $5000 \mathrm{~m}$. However, the degree of slope affects this. In the literature, various approaches and rules are used to determine walking time (Naismith 1892; Langmuir 1984). However, in our study, the hiking function of Tobler (1993), which considers the slope of the land, was chosen to calculate the walking times of the routes:

Time $($ hours $)=0.000166666^{*}\left(\operatorname{EXP}\left(3.5^{*}(\operatorname{ABS}(\operatorname{TAN}(\right.\right.$ Slope $\left.\left.)+0.05))\right)\right)$ (1)

In the application stage, all routes were first divided into line segments. The slope of each line segment and its actual length in the terrain were then calculated. Then, the walking time for each line segment was estimated using the above formula. Finally, the walking times of all line segments forming a hiking route were summed.

\section{Access to clean water}

Access to clean water was one of the main parameters, with access or no access to a water resource used as sub-parameters. The need for clean drinking water, to maintain the body's fluid balance during long walks especially, is an important parameter for the safety of hikers.

\section{Landscape Quality}

It emerged from the interviews with the participants in hiking activities that landscape quality was a 
Table 1 - Linear function types used to calculate the scores of continuous variables.

\begin{tabular}{|c|c|c|c|c|}
\hline Main parameters & Linear function type & Equation & $\mathbf{r}_{1}$ & $r_{2}$ \\
\hline Altitude & Less is better & $f(x)=1-\frac{\left(x-x_{1}\right)}{\left(x_{2}-x_{1}\right)}$ & & \\
\hline Slope & \multirow{3}{*}{ Optimum range } & \multirow{3}{*}{$\begin{array}{l}f(x)=1-\frac{\left(x-x_{1}\right)}{\left(r_{1}-x_{1}\right)} ; x_{1}<x<r_{1} \\
f(x)=0 ; r_{1}<x<r_{2} \\
f(x)=1-\frac{\left(x-r_{2}\right)}{\left(x_{2}-r_{2}\right)} ; r_{2}<x<x_{2}\end{array}$} & $-5^{\circ}$ & $+12^{\circ}$ \\
\hline Distance & & & $12000 \mathrm{~m}$ & $16000 \mathrm{~m}$ \\
\hline Walking time & & & $4 \mathrm{~h}$ & $6 \mathrm{~h}$ \\
\hline
\end{tabular}

In the equations, $f(x)$ is the score of sub-parameters between 0.1 and $1, x$ is the identified value of the sub-parameter, $x 1$ and $x 2$ are the minimum and maximum values, and $r 1$ and $r 2$ are the lower and upper threshold values.

Table 2 - Scores of sub-parameters for discrete variables.

\begin{tabular}{|l|l|r|}
\hline Main parameters & Sub-parameters & Score \\
\hline \multirow{4}{*}{ Aspect } & S, flat, SW, SE & 0.2 \\
\cline { 2 - 3 } & $\mathrm{N}$ & 0.6 \\
\cline { 2 - 3 } & $\mathrm{NE}, \mathrm{NW}$ & 0.8 \\
\cline { 2 - 3 } & $\mathrm{E}, \mathrm{W}$ & 0.4 \\
\hline \multirow{3}{*}{ Access to clean water resources } & Present & 1 \\
\cline { 2 - 3 } & Absent & 0 \\
\hline \multirow{4}{*}{ Landscape } & Good & 1 \\
\cline { 2 - 3 } & Average & 0.6 \\
\cline { 2 - 3 } & Bad & 0.4 \\
\hline
\end{tabular}

key factor in choosing walking routes in natural areas. Within the field of the study, aesthetically pleasing areas such as viewpoints, points of high visual value, and cultural landscape elements were considered important. Sub-parameters were evaluations of these as good, average or bad. Hatila Valley NP features a Vshaped valley offering unspoiled natural and cultural landscapes, with a richness of geological formations and vegetation.

The aspect parameter was defined using four groups of sub-parameters: (1) southerly, southeasterly, southwesterly and flat; (2) northerly aspects; (3) northeasterly and northwesterly aspects; (4) easterly and westerly aspects.

\section{Weighting the main parameters}

A pairwise comparison matrix was created to weight the parameters chosen based on the AHP. In this matrix, the relative importance of the parameters to each other was determined by face-to-face interviews with a group of 20 experts comprising academics from departments of landscape architecture, physical education and sports, and tour guides working in nature tourism. The significance scale developed by Saaty (1980) was used in the paired comparisons.

\section{Scoring the sub-parameters}

Continuous variables, such as altitude, slope, distance and walking time, were scored using linear scoring functions (Qi et al. 2009; Guo et al. 2017). The functions are listed in Table 1. Optimum range function was used for slope, distance and walking time, while less is better was used for altitude. On the other hand, discrete variables, such as aspect, access to clean water and landscape quality, which cannot be expressed by a numerical value, were scored on a scale of 0.1 to 1.0 (0.1, lowest; 1.0 , highest), based on the opinions of the 20 experts (see Table 2). Sub-parameters that adversely affected the hiking activity had lower scores; sub-parameters with positive effects received higher scores.

\section{Hiking Suitability Index of the routes}

Raster maps of the parameters used in this study were prepared in ArcGIS 10.2. First, a DEM of the study area was generated in the TIN data structure by using the contour lines $(10 \mathrm{~m}$ interval) of a $1 / 25000$-scale topographical map covering the study area. The DEM was then converted to a raster format (ESRI GRID format) with $10 \mathrm{~m}$ x $10 \mathrm{~m}$ cell size using the TIN to Raster operation of ArcGIS 10.2; slope, aspect and altitude maps of the area were generated based on the DEM in raster format. The roads within the forest to be evaluated as hiking routes were digitized from the forest management maps of the study field and transferred to ArcGIS. The linear function scores for slopes, altitude, distances and walking times, and sub-parameter scores for landscape quality, access to clean water and aspects were entered into the ArcGIS database as attributes. After generating the maps for the parameters, the calculated weights and sub-parameter scores were assigned to the respective layers in ArcGIS, and then the Weighted Sum Overlay Analysis was used to calculate the Hiking Suitability Index (HSI) value of each route. 
Table 3 - Pairwise comparison matrix.

\begin{tabular}{|l|r|r|r|r|r|r|r|r|}
\hline Parameter & Slope & Altitude & Length & Walking time & Landscape & Water resources & Aspect & Weights \\
\hline Slope & 1 & 2 & 3 & 5 & 6 & 7 & 9 & 0.3712 \\
\hline Altitude & $1 / 2$ & 1 & 2 & 3 & 4 & 6 & 8 & 0.2389 \\
\hline Length & $1 / 3$ & $1 / 2$ & 1 & 2 & 3 & 5 & 6 & 0.1586 \\
\hline Walking time & $1 / 5$ & $1 / 3$ & $1 / 2$ & 1 & 2 & 3 & 5 & 0.0993 \\
\hline Landscape & $1 / 6$ & $1 / 4$ & $1 / 3$ & $1 / 2$ & 1 & 2 & 3 & 0.0629 \\
\hline Water resources & $1 / 7$ & $1 / 6$ & $1 / 5$ & $1 / 3$ & $1 / 2$ & 1 & 3 & 0.0440 \\
\hline Aspect & $1 / 9$ & $1 / 8$ & $1 / 6$ & $1 / 5$ & $1 / 3$ & $1 / 3$ & 1 & 0.0251 \\
\hline
\end{tabular}

\section{Results and discussion}

\section{Weights of the main parameters}

The pairwise comparison matrix for weighting the parameters used in this study showed that slope obtained the highest weight value and aspect the lowest (Table 3). In other words, slope was the most important parameter in determining the level of suitability of hiking routes. This was followed by altitude, length, walking time, landscape quality, access to clean water and aspect. The consistency ratio for the matrix was calculated as 0.0459 . A consistency ratio value below 0.10 means that the decision matrix has a satisfactory level of consistency, and can be used without any adjustment (Zhang et al. 2004).

\section{Scores of the sub-parameters}

Two different approaches were used in the scoring of sub-parameters. In the first, length, walking time and slope sub-parameters were scored using standard, optimal range, scoring functions, while altitude was scored with a less is better function (Table 1). In the second approach, sub-parameters for aspect, water resources and landscape were scored according to expert opinions, reflecting their impact values on hiking (Table 2).

The optimum range function assigned 1 point to places with gentle descents and ascents, and where hiking was carried out comfortably (slopes between -5 and +12 degrees). The scoring function used for slope assigns a score in the range of $0-1$ where the slope is less than -5 degrees and greater than +12 degrees. To calculate the slope scores of the routes, each route was first divided into line segments. Then, the slope of each segment was calculated according to the direction of the route, using the scoring functions. Finally, a route's slope score was calculated by taking the average of the slope scores of all the line segments for the route. The slope scores with the highest weight coefficient varied between 0.789 (route 4) and 0.939 (route 5), on a scale of $0-1$ (Figure 5). These values showed that all roads in the Hatila Valley NP are suitable for hiking in terms of slope. Beeco et al. (2014), who looked at route preferences based on slopes, reported that hikers preferred routes with gentle ascents and descents.

An increase in altitude can reduce the suitability of a route for hiking, due to lower oxygen levels. Thus, in this study, altitude was scored using the less is better function. Researchers have reported that high-altitude areas are generally unsuitable for amateur hiking because of altitude sickness, especially at $2500 \mathrm{~m}$ and above (Peterson et al. 2018; Imray et al. 2010; Reisman et al. 2017). The lowest (0.242) and highest (0.965) altitude scores were for routes 2 and 6 , respectively

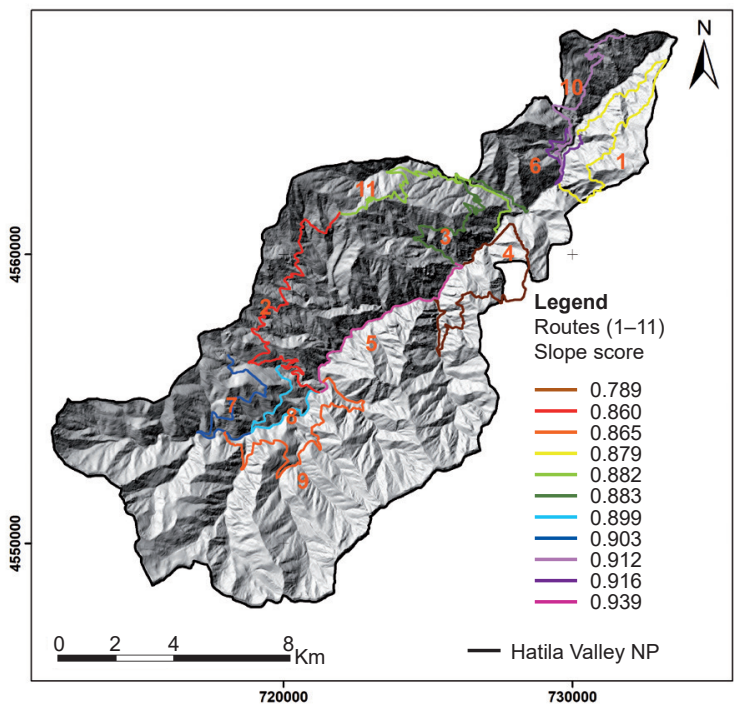

Figure 5 - Scores for the routes in terms of slope. (C) 2020 General directorate of mapping

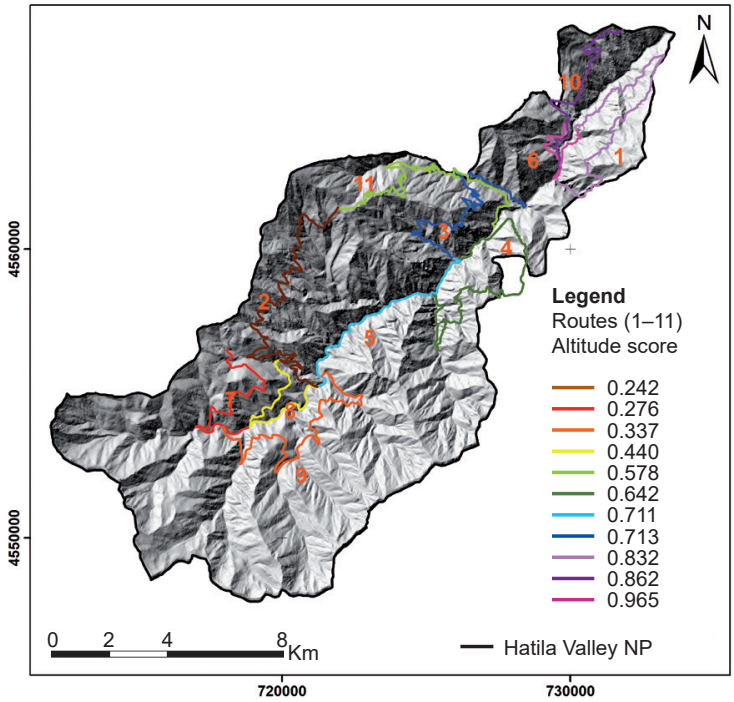

Figure 6 - Scores for the routes in terms of altitude. (C) 2020 General directorate of mapping 


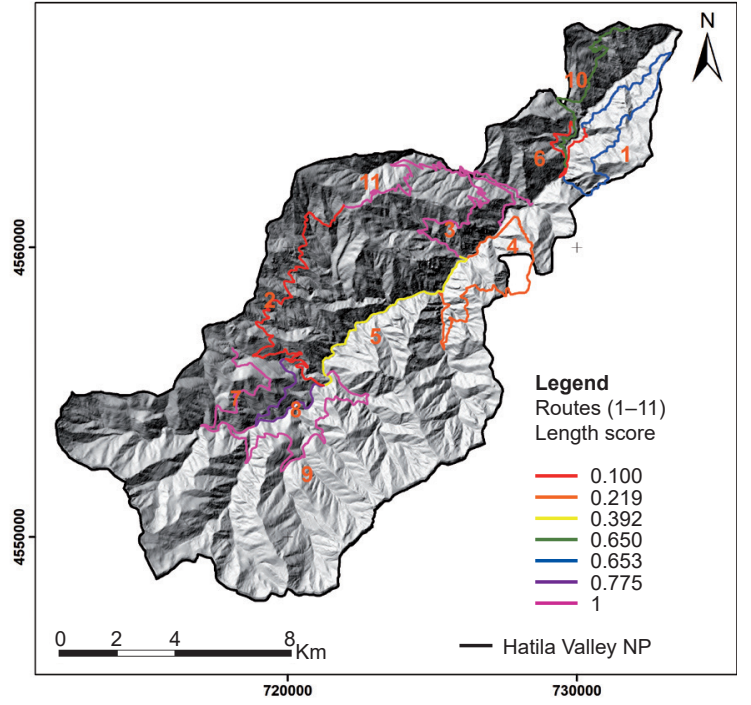

Figure 7 - Scores for the routes in terms of length. (C) 2020 General directorate of mapping

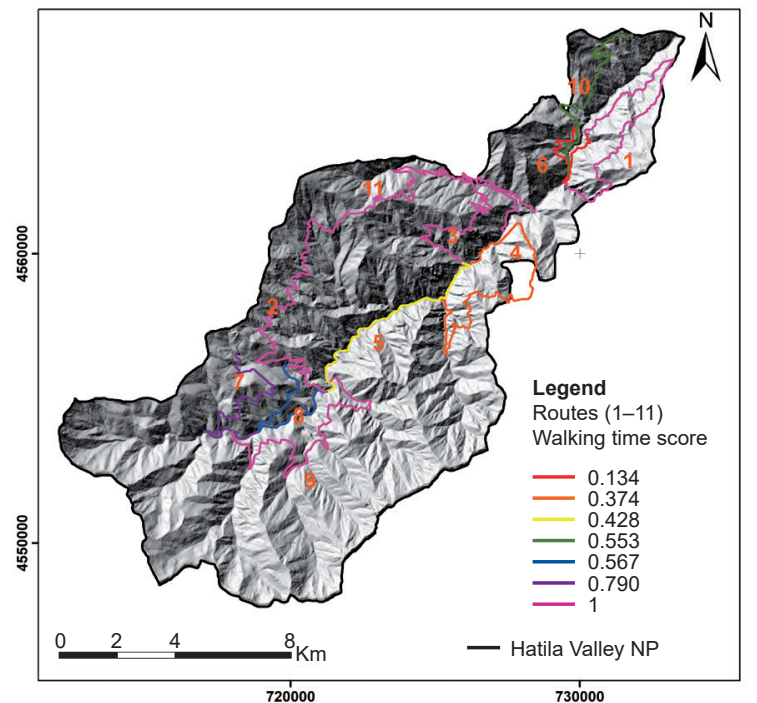

Figure 8 - Scores for the routes in terms of walking time. (C) 2020 General directorate of mapping

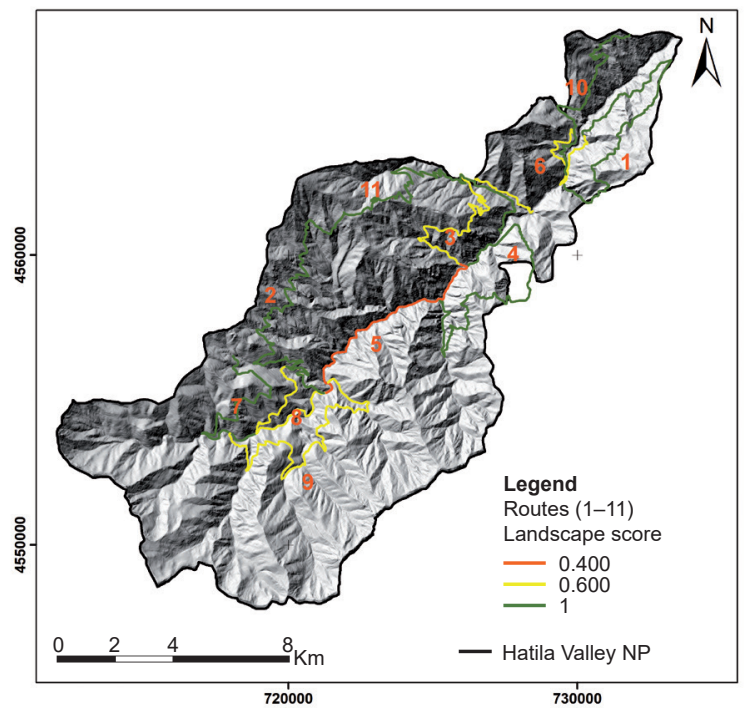

Figure 9 - Scores for the routes in terms of landscape quality. (C) 2020 General directorate of mapping

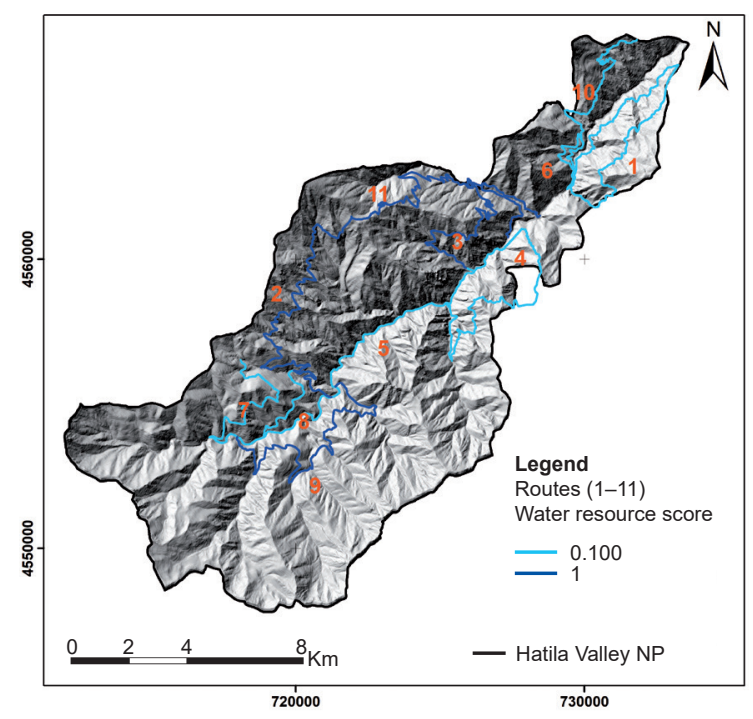

Figure 10 - Scores for the routes in terms of access to clean water. (C) 2020 General directorate of mapping

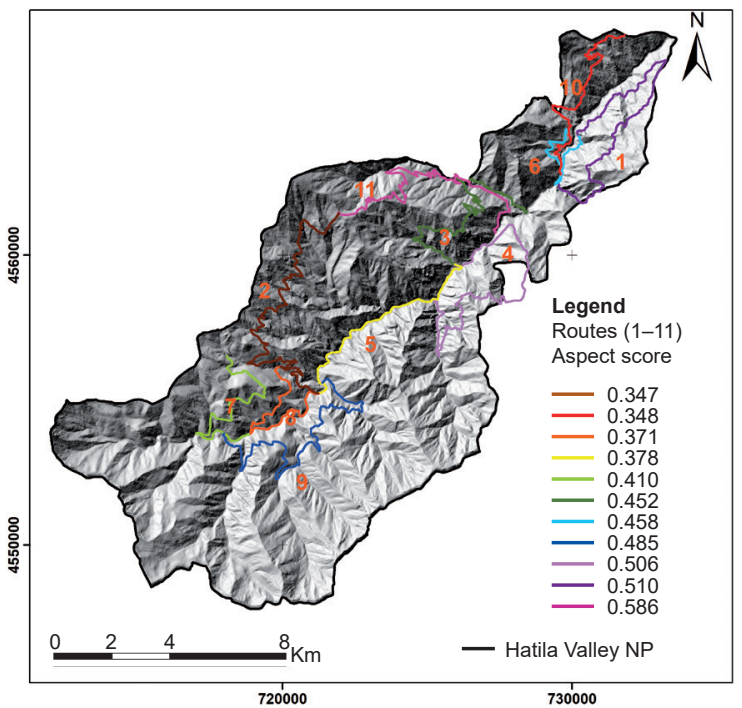

Figure 11 - Scores for the routes in terms of aspect. (C) 2020 General directorate of mapping

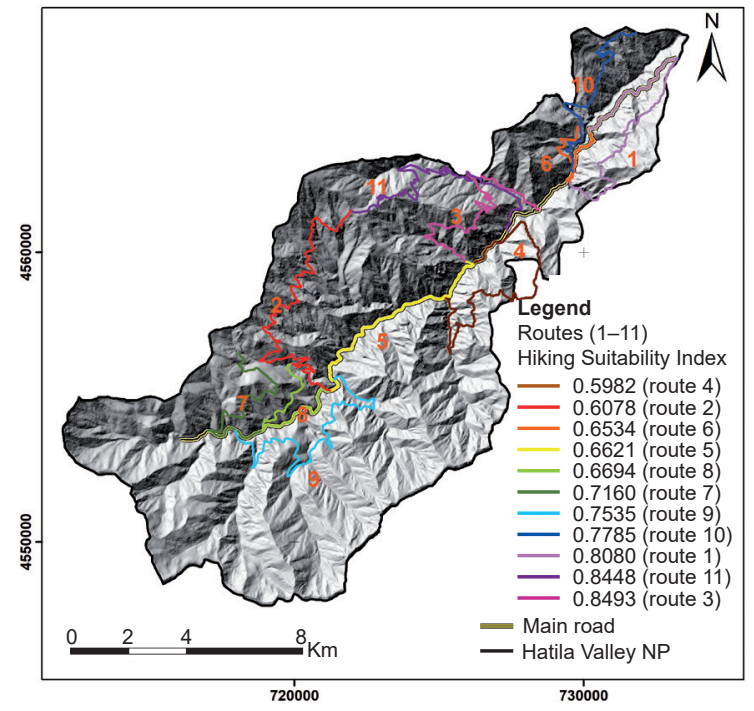

Figure 12 - Routes according to Hiking Suitability Index (HSI). (C) 2020 General directorate of mapping 
(Figure 6). Since the altitude in the Hatila Valley NP varies widely due to the topography, the routes' scores also varied significantly.

Problems with motivation and a lack of pleasure in the hiking activity have been reported for distances of less than $8000 \mathrm{~m}$, and various health problems occur at distances above $16000 \mathrm{~m}$ (Saayman \& Vilioen 2016). Thus, the optimum range function was used to score length, and the highest score was assigned to the range 12000-16000 m. For distance, route scores ranged from 0.1 to 1.0. Routes 6 and 2 had the lowest scores because they are too short; routes 3, 11, 7 and 9 scored increasingly highly (Figure 7).

The optimum range function was used to score the walking time. The highest score was given to a walking time of between 4 and 6 hours, while the scores given to durations above and below this were gradually decreased. The lowest score for walking time was for route $6(0.134)$, and the highest for routes 1, 2, 3, 9 and 11 (Figure 8). Route 6 had the lowest score because its walking time is much lower than the lower limit of the optimum range due its length. Saayman \& Viljoen (2016) examined the success criteria for different routes in completely natural environments in Kruger $\mathrm{NP}$ and found that a walking time of less than one hour led to insufficient motivation. Other researchers have reported that participants in hikes stopped to look at the landscape, take photographs, taste edible plants and study animal behaviour (Korzeniewski et al. 2015), and therefore argued that the walking time could not be calculated on the basis of distance, as Naismith did (Scarf 2007).

Hikers prefer unspoiled natural areas, viewpoints, the existence of cultural landscape elements, and areas of high landscape value. 1 point was given for good landscapes based on expert opinions; areas with average and poor landscapes received 0.6 and 0.4 points, respectively. In terms of landscape quality, routes 1, 2, 4, 7 and 10 received the highest score (1.0), followed by routes 3, 6, 8 and $9(0.6)$; route 5 received the lowest $(0.4)$ (Figure 9). The study area in this research has high landscape quality, with properties such as intact natural and unique resource values, being home to rare geological formations and plant diversity, having a V-shaped valley, and having viewpoints throughout. Route $5 \mathrm{had}$ the lowest score because it is located in the narrow valley bottom and therefore the view is blocked by the steep mountain slopes. Studies which investigated the effect of landscape on whether individuals carried out hiking found that natural and cultural landscape elements determined preferred hiking routes (Beeco et al. 2014; Mohd Taher et al. 2015; Van Berkel et al. 2018; Tieskens et al. 2018; Peterson et al. 2018).

Access to clean water was scored using two subparameters: access and no access. While hiking routes with potable water were assigned 1, routes without received 0.1 (Figure 10). Routes 2, 3, 9 and 11, which all allowed easy access to drinking water, scored with 1.0, while the score was 0.1 for routes $1,4,5,6,7,8$ and 10 , where access to water was difficult. It is especially important to meet the body's water requirements during hiking activities. If the water lost through dehydration is not replaced by clean drinking water, the body will use metabolic water, and as a result fatigue and exhaustion will occur. Although carrying extra water may be a solution, the weight carried has an effect on walking performance, and accessible drinking water along the route positively affects route preferences (Andrus \& Herbst 1979). In their study, Boulware et al. (2003) emphasized the importance of clean water during group activities.

As hiking was not possible in Hatila Valley NP in winter due to the difficulty of reaching the area, the evaluation was based on the spring and summer months. Because hiking activities are mainly conducted in summer months, shady areas are preferred. As a result, viewpoints facing northeast and northwest received 0.8 , those facing north received 0.6 , those facing east and west received 0.4 , and 0.2 was assigned to those facing south, southeast, southwest and that were flat. As there are multiple viewpoints along each route, scoring was done by considering the orientation of viewpoints along each route. Based on this, route 11 received the highest score (0.586), and route 2 received the lowest (0.347) (Figure 11). Since north- and south-facing were the most common aspects throughout the Hatila Valley NP, aspect resulted in low scores on almost all routes.

\section{The Hiking Suitability Index (HSI) of routes}

The hiking suitability index (HSI) values of routes are given in Figure 12, and the scores of the parameters used in determining these values in Figure 13. Route 3, where the parameters for length, time and access to water all scored 1.0, was the most suitable forest road for hiking, giving it the highest HSI (0.8493).

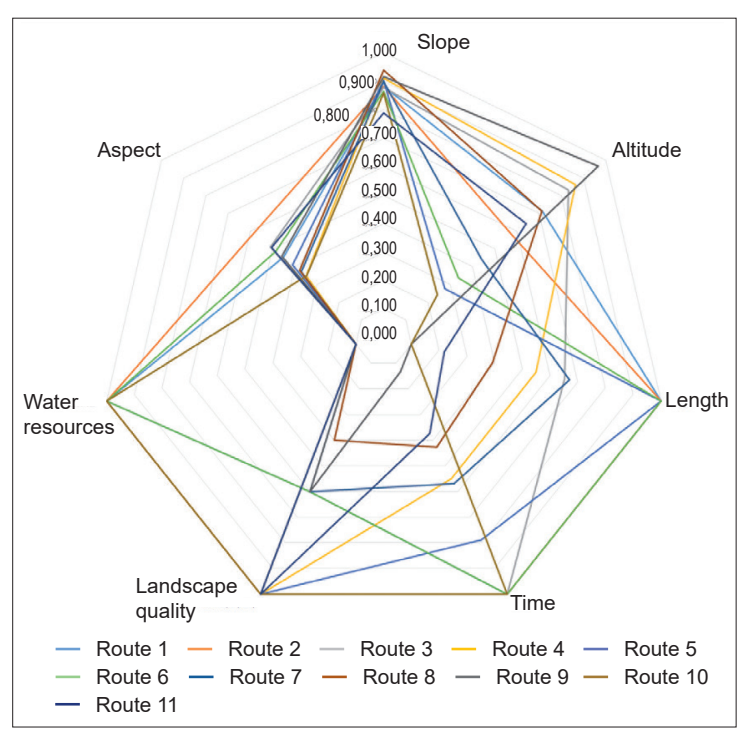

Figure 13 - Radar chart of parameter scores in Hiking Suitability Index (HSI). 
It was a limiting factor that the altitude of route 11 , which ranked second overall (0.8448), was above the optimum limits (Figure 13). Routes 1, 10 and 7 were in the third (0.8080), fourth (0.7785), and fifth (0.7160) places respectively. The limiting factor of the three routes was access to drinking water. For route 9, which ranked sixth with a score of 0.6857 , the most significant limiting factor was altitude. The limiting factor for routes 8 and 5, ranked respectively seventh with a score of 0.6694 and eighth with 0.6621 , was access to drinking water. Unlike the other routes, two different parameters (length and access to drinking water) reduced the score of route $6(0.6534)$, which ranked ninth. Length was the most significant parameter in decreasing the score of route 2 , which ranked tenth with 0.6078 . Route 4 ranked last, with 0.5982 ; access to water was the most important limiting factor for this route. The most significant parameter governing the route ranking was access to drinking water, followed by length and altitude. Since a quantitative evaluation method based on weighting was used in this study, the low score of one parameter changed the suitability of the route, even if other parameters scored high.

Studies conducted to determine the reasons for choosing hiking routes and hiker behaviour state that the most important considerations are duration and length (Taczanowska et al. 2008b). Other studies have used properties such as distance, facilities and landscape characteristics (De Valck et al. 2017); personal characteristics of the hiker, such as gender, age, education, occupation, marital status and income, were also factors in user behaviour and route preferences (Ping et al. 2017).

In this study, the first of its type, we used a quantitative method to investigate the suitability of forest roads for hiking. Although Taczanowska et al. (2008b) reported that there was a match between the expected and actual behaviours of hikers in terms of the distance and duration of hikes, the empirical results of this study need to be verified using a quantitative method, which will increase the usability of the method in other areas.

In this study, summer conditions and the opinions of active hikers were taken into consideration in determining the evaluation parameters; the use of the area in other seasons and other user features, such as age and gender, were not evaluated. This situation may limit the use of the model elsewhere. However, age is decisive in individuals' behaviour and activity preferences. Tachel \& Backhaus (2011) stated that older people as a visitor group were very interested in information about the NP, took their time on the trails, and spent more time on observation; what they most disliked was crowding and noise.

The landscape quality of routes was also evaluated and scored qualitatively in this study. To increase the reliability of the model, future studies will evaluate landscape properties quantitatively.

\section{Conclusion}

The current global pandemic has changed the recreational habits of people, encouraging them to move away from crowded urban environments towards natural areas. Ensuring the sustainable use of areas with sensitive resource value such as NPs has become even more important, and interest has increased in the fast and reliable assessment of infrastructure suitability for recreational activities in protected areas. Models created using GIS and multiple decision analyses such as AHP can be used for these purposes, as shown in this study, which evaluated the recreational potential of existing forest roads in Hatila Valley NP and concluded that they could be used for hiking. This study also concludes that GIS-based models could be used in the decision-making process and to measure the parameters. Finally, the reliability of the model could be enhanced by considering other user profiles in creating the parameters.

\section{References}

Andrus, C.D. \& R.L. Herbst 1979. The Third Nationwide Outdoor Recreation Plan. Heritage Conservation and Recreation Service.

Anşin, R., Z.C. Özkan \& Ö. Eminağaoğlu 2000. A research on structure of vegetation of Artvin-Atila (Hatilla) Valley National Park. Artvin Corub University Journal of Forestry Faculty 1(1): 59-71.

Ardahan, F. \& M. Mert 2013. The validity and reliability of motivational factors scale and the benefits scale of participating in trekking activities for Turkish population. International Journal of Human Sciences 10(2): 338-355.

Arnberger, A., C. Branderburg \& A. Muhar (ed.) 2002. Monitoring and Management of Visitor. Flows in Recreational and Protected Areas. Vienna, Austria. Institute for Landscape Architecture and Landscape Management, BOKU University.

Baez, L.A. 2002. Sky Walk-Sky Trek: A Successful Community Project in the Mountains of Monteverde, Costa Rica. Mountain Research and Development 22(2): 128-131.

Beeco, J.A., H. Jeffrey \& M. Brownlee 2014. GPS Visitor Tracking and Recreation Suitability Mapping: Tools for Understanding and Managing Visitor Use. Landscape and Urban Planning 127: 136-145. Doi: 10.1016/J.LANDURBPLAN.2014.04.002

Bell, S. 1997. Design for Outdoor Recreation. London.

Bhaumik, G., D. Dass, H. Lama \& S.K.S. Chauchan 2008. Maximum Exercise Responses of Men and Women Mountaineering Trainees on Induction to High Altitude (4350 m) by Trekking. Wilderness \& Environmental Medicine 19(3): 151-156.

Boulware, D.R., W.W. Forgey \& W.J. Martin 2003. Medical risks of wilderness hiking. The American Journal of Medical Sciences 114(4): 288-293. 
Bunruamkaew, K. \& Y. Murayama 2011. Site suitability evaluation for ecotourism using GIS \& AHP: A case study of surat Thani Province, Thailand. Procedia Social and Behavioral Sciences 21: 269-278.

Chakrabarty, A. 2011. Ecotourism Development and Security Restructuring: A GI Based Planning for Peaceful Dissuasion of Anarchism in Forest Provinces of India. Procedia Social and Behavioral Sciences 21: 108-115.

Den Breejen, L. 2007. The Experiences of Long Distance Walking: A Case Study of the West Highland Way in Scotland. Tourism Management 28 (6): $1417-$ 1427. Doi: 10.1016/j.tourman.2006.12.004

De Valck, J., D. Landyut, S. Broekx, I. Liekens, L. De Nocker \& L. Vranken 2017. Outdoor Recreation in Various Landscapes: Which Site Characteristics Really Matter? Land Use Policy 65: 186-197.

Erbaş, M., H. Şahin, H. Soyer, F. Kantar \& Z. Alkış 2011. Walking analysis on the virtual globe. Türkiye Harita Bilimsel ve Teknik Kurultay1, 18-22 April 2011, Ankara, Turkey.

Fritz, S. \& S. Carver 1998. Modelling Naismith's rule: Implications for the wilderness indicator naturalness. GIS Research UK $6^{\text {th }}$ National Conference.

García-Frapolli, E., B. Ayala-Orozco, M. BonillaMoheno, C. Espadas-Manrique \& G. Ramos-Fernández 2007. Biodiversity conservation, traditional agriculture and ecotourism: Land cover/land use change projections for a natural protected area in the northeastern Yucatan Peninsula, Mexico. Landscape Urban Planning 83(2-3): 137-153.

Geneletti, D. \& D. Dawa 2009. Environmental impact assessment of mountain tourism in developing regions: A study in Ladakh, Indian Himalaya. Environmental Impact Assessment Review 29(4): 229-242.

Gunes, G. \& L. Hens 2007. Ecotourism in Oldgrowth Forest in Turkey: Kure Mountains Experience. Mountain Research and Development 27(3): 281-283.

Guo T., S. Jardon, R. Moore \& L.C. Schultz 2017. Integrating off-site visitor education into landscape conservation and management: An examination of timing of educational messaging and compliance with low-impact hiking recommendations. Landscape and Urban Planning 164: 25-36. Doi: 10.1016/j. landurbplan.2017.03.013

Hai-ling, G., W. Liang-Qiang \& L. Yong-pen 2011. A GIS-based approach for information management in ecotourism region. Procedia Engineering 15: 19881992.

Imray, C., W. Alex, S. Andrew \& R. Robert 2010. Acute Mountain Sickness: Pathophysiology, Prevention, and Treatment. Progress in Cardiovascular Diseases 52(6): 467-484. Doi: 10.1016/j.pcad.2010.02.003

Kaczynski, A.T. \& K.A. Henderson 2007. Environmental Correlates of Physical Activity: A Review of Evidence about Parks and Recreation. Leisure Sciences 29(4): 315-354. Doi: 10.1080/01490400701394865

Kanai, M., F. Nishihara, T. Shiga, H. Shimada \& S. Saito 2001. Alterations in autonomic nervous control of heart rate among tourists at 2700 and $3700 \mathrm{~m}$ above sea level. Wilderness and Environmental Medicine 12: 8-12.

Kaplan, A. \& F. Ardahan 2013. Doğa sporları yapan bireylerin profilleri, Doğa sporu yapma nedenleri ve elde ettikleri kaydalar. Antalya örneği. The Blacksea Journal of Social Sciences 5(8): 94-113. [In Turkish]

Kiper, T. 2011. The determination of nature walk routes regarding nature tourism in north-western Turkey, Şarköy District. Journal of Food, Agriculture \& Environment 9(3,4): 622-632.

Korzeniewski, K., A. Nitsch-Osuch, A. Guzek \& D. Juszczak 2015. High Altitude Pulmonary Edema in Mountain Climbers. Respiratory Physiology \& Neurobiology 209: 33-38. Doi: 10.1016/J.RESP.2014.09.023.

Kramer, A. \& R. Roth 2002. Spatial Requirements of Outdoor Sports in Nature Park. Southern Black Forest - GIS-Based Conflict Analysis and Solutions for Visitor Flow Management. In: Arnberger, A., C. Brandenburg \& A. Muhar (eds.), Monitoring and Management of Visitor Flows in Recreational and Protected Areas Conference Proceedings: 33-39.

Kurdoğlu, O. \& B.A. Çokçalışkan 2011. Assessing the Effectiveness of Protected Area Management in the Turkish Caucasus. African Journal of Biotechnology 10(75): 17208-17222.

Langmuir, E. 1984. Mountaincraft and Leadership. Scottish Sports Council, Edinburgh, Scotland.

Li, R., Z. Lu \& J. Li 2012. Quantitative calculation of eco-tourist's landscape perception: Strength, and spatial variation within ecotourism destination. Ecological Informatics 10: 73-80. Doi: 10.1016/j. ecoinf.2012.03.009

Magyari-Saska, Z. \& Ş. Dombay 2012. Determining minimum hiking time using DEM. Geographia Napocensis $\mathrm{VI}(2)$ : 124-129.

Mason, P. 2005. Visitor Management in Protected Areas: From 'hard' to 'soft' approaches? Current Issues in Tourism 8(2-3): 181-194. Doi: 10.1080/13683500508668213

Nahuelhual, L., A. Carmona, P. Lozada, A. Jaramillo \& M. Aguayo 2013. Mapping recreation and ecotourism as a cultural ecosystem service: An application at the local level in Southern Chile. Applied Geography 40: 71-82.

Naismith, W.W. 1892. Cruach Ardran, Stobinian, and Ben More. The Scottish Mountaineering Club Journal 2(3): 136.

Nepal, S. 2006. Mountain ecotourism and sustainable development: Ecology, Economics, and Ethics. Mountain Research and Development 22(2): 104-109. Doi: $10.2307 / 3674310$

Northern Research Station n.d. Forest Road Construction and Maintenance. Available at: https://www. nrs.fs.fed.us $/ \mathrm{fmg} / \mathrm{nfmg} / \mathrm{docs} / \mathrm{mn} /$ roads.pdf (accessed 22/09/2020)

Nyaupane, G.P., D.B. Morais \& A.R. Graefe 2004. Nature tourism constraints: A cross-activity comparison, Annals of Tourism Research 31(3): 540-555. Doi: 0.1016/j.annals.2004.01.006 
Oksuz, S. 2020. Hiking, trekking ve dağcilik farklari nelerdir? [A report of Turkish Mountaineering Federation] Available at: https://drive.google.com/ file/d/18ownbW7Jdqdb61AEs_ovxGTVXyMxbIl-/ view (accessed 22/09/2020) [In Turkish]

Paul, B. \& S. Hudson 2003. Emergence of Mountain-Based Adventure Tourism. Annals of Tourism Research 30(3): 625-643. Doi: 10.1016/S01607383(03)00043-4

Peterson, B., M. Brownlee \& J.L. Marion 2018. Mapping the Relationships between Trail Conditions and Experiential Elements of Long-Distance Hiking. Landscape and Urban Planning 180: 60-75. Doi: 10.1016/j.landurbplan.2018.06.010

Ping, L., B. Zhou \& C. Ryan 2017. Hiking in China: A Fuzzy Model of Satisfaction. Tourism Management Perspective: 90-97. Doi: 10.1016/j.tmp.2017.03.003

Pitman, A., M. Zanker, J. Gamper \& P. Andritsos 2012. Individualized hiking time estimation. Proceedings of $201223^{\text {rd }}$ International Workshop on Database and Expert Systems Applications, DEXA, 3-7 September, Vienna, Austria: 101-105.

Qi, Y., J.L. Darilek, B. Huang, Z. Yongcun, W. Sun \& Z. Gu 2009. Evaluating soil quality indices in an agricultural region of Jiangsu Province, China. Geoderma 149: 325-334.

Rees, W.G. 2004. Least-cost paths in mountainous terrain. Computers \& Geosciences 30: 203-209.

Reisman, J., D. Deonarain \& B. Basnyat 2017. Impact of a newly constructed motor vehicle road on altitude illness in the Nepal Himalayas. Wilderness Environment Media 28(4): 332-338.

Rival, L.M. 2002. Trekking Through History: The Huarani of Amazonian Ecuador.

Saaty, T.L. 1980. The Analytic Hierarchy Process. Planning, Priority Setting, Resource Allocation. New York, NY, USA.

Saayman, M. \& A. Viljoen 2016. Who Are Wild Enough to Hike a Wilderness Trail? Journal of Outdoor Recreation and Tourism 14: 41-51. Doi: 10.1016/j. jort.2016.04.004

Scarf, P. 2007. Route choice in mountain navigation, Naismith's rule, and the equivalence of distance and climb. Journal of Sports Sciences 25(6): 719-726.

Scarf P. \& P. Grehan 2005. An empirical basis for route choice in cycling. Journal of Sports Sciences 23(9): 919-925.

Schirpke, U., R. Scolozzi, R. Da Re, M. Masiero, D. Pellegrino \& D. Marino 2018. Recreational ecosystem services in protected areas: A survey of visitors to $\mathrm{Na}$ tura 2000 sites in Italy. Journal of Outdoor Recreation and Tourism 21: 39-50.

Solnit, R. 2001. Wanderlust: A History of Walking. New York.

Sonneveld, B.G.J.S., M.A. Keyzer, K. Georgis, S. Pande, A. Seid \& A. Takele 2009. Following the Afar: Using remote tracking systems to analyze pastoralists' trekking routes. Journal of Arid Environments 73: 1046-1050.
Tachel, A. \& N. Backhaus 2011. Perception and Needs of Older Visitors in the Swiss National Park-a Qualitative Study of Hiking Tourists Over 55. eco.mont - Journal on protected mountain areas research and management 3(1): 47-50.

Taczanowska, K., A. Arnberger \& A. Muhar 2008a. Exploring Spatial Behavior of Individual Visitors as Background for Agent-Based Simulation. In: Gimblett, R. \& H. Skov-Petersen (eds.), Monitoring, Simulation and Management of Visitor Landscapes: 159-174.

Taczanowska, K., A. Muhar \& C. Brandenburg 2008b. Potential and limitations of GPS tracking for monitoring spatial and temporal aspects of visitor behaviour in recreational areas. In: Raschi, A. \& S. Trampetti (eds.), The Fourth International Conference on Monitoring and Management of Visitor Flows in Recreational and Protected Areas, Montecatini Terme, Italy, 14-19 October 2008: 451-456.

Taher, S.H.M., A.J. Salamiah, N. Sumarjan \& A. Norliza 2015. Examining the Structural Relations among Hikers' Assessment of Pull-Factors, Satisfaction and Revisit Intentions: The Case of Mountain Tourism in Malaysia. Journal of Outdoor Recreation and Tourism 12: 82-88. Doi: 10.1016/j.jort.2015.11.012.

Tieskens, K.F., B.T. Van Zanten, C.J.E. Schulp \& P.H. Verburg 2018. Aesthetic Appreciation of the Cultural Landscape through Social Media: An Analysis of Revealed Preference in the Dutch River Landscape. Landscape and Urban Planning 177: 128-137. Doi: 10.1016/j.landurbplan.2018.05.002.

Tobler, W. 1993. Three Presentations on Geographical Analysis and Modeling. National Center for Geographic Information and Analysis, Technical Report, 93-1, University of California, Santa Barbara, CA.

Tomczyk, A.M. 2011. A GIS assessment and modelling of environmental sensitivity of recreational trails: The case of Gorce National Park, Poland. Applied Geography 31: 339-351.

Tsaur, S.-H., Y.-C. Lin \& J.-H. Lin 2006. Evaluating ecotourism sustainability from the integrated perspective of resource, community and tourism. Tourism Management 27: 640-653.

Van Berkel, D.B., P. Tabrizian, M.A. Dorning, L. Smart, D. Newcomb, M. Mehaffey, A. Neale \& R.K. Meentemeyer 2018. Quantifying the visual-sensory landscape qualities that contribute to cultural ecosystem services using social media and LiDAR. Ecosystem Services 31: 326-335.

Vias J., J. Rolland, M.L. Gomez, C. Ocana \& A. Luque 2018. Recommendation System to Determine Suitable and Viable Hiking Routes: A Prototype Application in Sierra de las Nieves Nature Reserve (southern Spain). Journal of Geographical System 20: 275-294.

Wagner, D.R, J.D. Fargo, D. Parker, K. Tatsugawa \& T.A. Young 2006. Variables Contributing to Acute Mountain Sickness on the Summit of Mt Whitney. Wilderness and Environmental Medicine 17: 221-228. 
Weaver, D. 2002. Asian Ecotourism: Patterns and Themes. Tourism Geographies 4(2): 153-172. Doi: 10.1080/14616680210124936

Ween, G. \& S. Abram 2012. The Norwegian Trekking Association: Trekking as Constituting the Nation. Landscape Research 37(2): 155-171. Doi: 10.1080/01426397.2011.651112

Yllmaz, T. \& Y. Memlük 2008. Vadilerde Rüzgâr ve Güneş Hareketlerine Bağlı Planlama ve Tasarım Olanakları, Ankara Büyükesat Vadisi Örneği. Journal of Mediterranean Agricultural Sciences 21(2): 193-204. [In Turkish]

Zhang, B., Y. Zhang, D. Chen, R.E. White \& Y. Li 2004. A quantitative evaluation system of soil productivity for intensive agriculture in China. Geoderma 123: 319-331. Doi: 10.1016/J.GEODERMA.2004.02.015

\section{Authors}

Hilal Turgut - corresponding author

is an Associate Professor at Karadeniz Technical University, Department of Landscape Architecture. Her main interests are landscape planning, protected areas and Geographic Information Systems. Karadeniz Technical University, Department of Landscape Architecture, 61010, Trabzon, Turkey

\section{Ayse Yavuz Ozalp}

is an Associate Professor at Artvin Çoruh University, Faculty of Engineering, Department of Geomatics. Her main interests are land administration, cadastres, land valuation and Geographical Information Systems. E-mail: ayavuzozalp@artvin.edu.tr

\section{Halil Akinci}

is an Associate Professor at Artvin Coruh University, Turkey. He earned his PhD at Karadeniz Technical University, Trabzon, Turkey. His research focus is on Geographic Information Systems, National Spatial Data Infrastructure, multicriteria decision analysis, risk mapping for natural hazards, and Geospatial web services.

1 Artvin Çoruh University, Department of Geomatics Engineering, 08100, Artvin, Turkey 